\title{
PENGEMBANGAN LKPD BERBASIS PEMBELAJARAN PENEMUAN UNTUK MENINGKATKAN KEMAMPUAN LITERASI SAINS PESERTA DIDIK PADA MATERI KIMIA SMA
}

\section{DEVELOPMENT OF STUDENT ACTIVITIES SHEETS BASED ON DISCOVERY LEARNING TO INCREASE THE HIGH SCHOOL STUDENT SCIENCE LITERATION ON CHEMISTRY TOPIC}

\author{
Izzatunnisa Izzatunnisa ${ }^{1}$, Yayuk Andayani ${ }^{1 *}$, Aliefman Hakim² \\ ${ }^{1}$ Program Studi Magister Pendidikan IPA, Universitas Mataram, Indonesia \\ ${ }^{2}$ Program Studi Pendidikan Kimia, jurusan Pendidikan MIPA, FKIP, Universitas Mataram, Indonesia \\ *Email : yayukmtr@gmail.com
}

Diterima: 21 Juni 2019. Disetujui: 21 Juni 2019. Dipublikasikan: 31 Juli 2019

\begin{abstract}
Abstrak: Telah dilakukan penelitian pengembangan LKPD berbasis pembelajaran penemuan pada materi larutan elektrolit dan nonelektrolit. Penelitian ini bertujuan untuk mengetahui: 1) kelayakan pengembangan LKPD secara teoritis; 2) kepraktisan penggunaan LKPD berbasis pembelajaran penemuan; dan 3) keefektifan penerapan LKPD berbasis pembelajaran penemuan. Prosedur pengembangan yang digunakan dalam penelitian ini, yaitu model Dick \& Carey (analisis kebutuhan dan identifikasi tujuan umum, analisis pembelajaran, analisis pembelajar dan konteks, merumuskan tujuan khusus, mengembangkan instrumen penilaian, mengembangkan strategi pembelajaran, mengembangkan dan memilih bahan pembelajaran, evaluasi formatif, melakukan revisi, serta evaluasi sumatif). Hasil yang diperoleh dari penelitian ini adalah 1) LKPD berbasis pembelajaran penemuan pada materi larutan elektrolit dan nonelektrolit sangat layak digunakan sebagai media pembelajaran dikarenakan telah memenuhi syarat kelayakan secara teoritis dengan persentase rata-rata LKPD sebesar 89,33\% dan termasuk dalam kriteria sangat layak, 2) LKPD berbasis pembelajaran penemuan sangat praktis dan mudah digunakan oleh guru dan peserta didik dengan rata-rata respon sebesar $86,79 \%$ dan termasuk dalam kategori sangat baik atau praktis; dan 3) LKPD berbasis pembelajaran penemuan efektif meningkatkan kemampuan literasi sains peserta didik dengan skor $N$-gain sebesar 0,36 dan termasuk dalam kategori sedang. Berdasarkan hasil tersebut dapat disimpulkan bahwa LKPD berbasis pembelajaran penemuan layak, praktis, dan efektif dalam meningkatkan kemampuan literasi sains peserta didik pada materi larutan elektrolit dan nonelektrolit.
\end{abstract}

Kata Kunci: LKPD, pembelajaran penemuan, literasi sains

\begin{abstract}
Research has been carried out on developing student activity sheets based on discovery learning in electrolyte and nonelectrolyte solution material. This study aims to find out: 1) the feasibility of developing a sheet of student activities theoretically; 2) the practicality of using student activity sheets based on discovery learning; and 3) the effectiveness of applying the student activity sheet based on discovery learning. The development procedures used in this study, namely the Dick \& Carey model (assess need to identify goals, conduct instructional analysis, analyze learners and context, write performance objectives, develop assessment instruments, develop instructional strategy, develop and select instructional material, design and conduct formation evaluation, revise instruction, and design and conduct summative evaluation). The results obtained from this study are 1) sheets of student activities based on discovery learning in electrolyte and nonelectrolyte solution material is very feasible to use as a learning medium because it has met the feasibility requirements theoretically with the average percentage of student activity sheets of $89.33 \%$ and included in the criteria very feasible, 2) sheets of student activities based on discovery learning are very practical and easy to use by teachers and students with an average response of $86.79 \%$ and included in the category of very good or practical; and 3) sheets of student activities based on effective discovery learning to improve the scientific literacy skills of students with an $\mathrm{N}$-gain score of 0.36 and included in the medium category. Based on these results it can be concluded that the student activity sheet based on discovery learning is feasible, practical, and effective in improving students' scientific literacy skills in electrolyte and nonelectrolyte solution materials.
\end{abstract}

Keywords: student activity sheets, discovery learning, scientific literacy

\section{PENDAHULUAN}

Pembelajaran kimia yang baik adalah pembelajaran yang dapat memberikan makna dan pemahaman proses sains kepada peserta didik dengan baik, untuk itu pendidik perlu mengaplikasikan dua hal ini di dalam proses pembelajarannya, dengan tujuan agar peserta didik dapat menghubungkan konsep-konsep kimia dengan kehidupan sehari-hari dan mendorong mereka untuk mengkonstruksikan pemahamannya sendiri dari materi yang telah dipelajari [1]. 
Berdasarkan hasil observasi awal yang telah dilakukan, diketahui bahwa masih banyak peserta didik yang mengalami kesulitan dalam mengaplikasikan konsep-konsep kimia ke dalam kehidupan sehari-harinya. Ini dikarenakan guru kurang melatih dan mengembangkan pemahaman sains peserta didik untuk memperdalam pengetahuan mereka terkait dengan isu-isu sains sesuai dengan tuntutan PISA, akibatnya literasi sains peserta didik menjadi rendah serta pembelajaran kimia menjadi kurang bermakna.

Literasi sains merupakan kemampuan untuk memahami proses sains dan mendapatkan informasi ilmiah secara bermakna yang tersedia di kehidupan sehari-hari [2]. Literasi sains merupakan keterampilan yang penting dan dibutuhkan dalam era digital saat ini sebab terdapat banyak permasalahanpermasalahan yang berkaitan dengan pengetahuan dan teknologi, serta memberdayakan masyarakat untuk membuat keputusan pribadi dan berpartisipasi dalam perumusan kebijakan publik yang berdampak pada kehidupan mereka [3].

PISA (Programme for International Student Assessment) menetapkan empat aspek penilaian dalam literasi sains, yaitu a) Konteks: dalam literasi sains melibatkan isu-isu yang sangat penting dalam kehidupan sehari-hari baik secara personal, lokal atau nasional, dan global; b) Kompetensi: dalam literasi sains terbagi menjadi tiga aspek, yaitu menjelaskan fenomena secara ilmiah, mengevaluasi dan merancang inkuiri ilmiah, serta menginterpretasi data dan bukti secara ilmiah; c) Pengetahuan: dalam literasi sains terdiri dari konten, prosedural, dan epistemic; dan c) Sikap: dalam literasi sains, yaitu minat terhadap sains, kepedulian terhadap lingkungan, dan mengevaluasi pendekatan ilmiah untuk penyelidikkan [4].

Salah satu faktor yang dapat menunjang proses pembelajaran kimia atau sains untuk memberikan kebermaknaan dan membentuk kemampuan literasi sains peserta didik adalah dengan menyediakan bahan ajar yang berkualitas dan sesuai dengan konteks pendidikan kimia atau sains, karena pada dasarnya pembelajaran kimia atau sains lebih menekankan pada pemberian pengalaman langsung dengan tujuan untuk mengembangkan kompetensi peserta didik agar dapat menjelajahi dan memahami alam sekitar secara ilmiah [5].

Hasil observasi awal menunjukkan bahwa guru menggunakan menggunakan LKPD dalam melengkapi sumber belajarnya, namun LKPD yang digunakan oleh guru dirasa masih kurang untuk melatih dan mengembangkan kemampuan literasi sains peserta didik dalam menjelaskan fenomena secara ilmiah, mengevaluasi dan merancang penyelidikan ilmiah, serta menginterpretasi data dan bukti secara ilmah melalui prosedur kerja ilmiah, sehingga LKPD yang digunakan guru tidak dapat memberikan kebermaknaan kepada peserta didik.
Alternatif solusi yang diberikan oleh peneliti agar peserta didik dapat mengembangkan pemahaman sains dalam literasi sains dan memberikan kebermaknaan dalam pembelajaran kimia, yaitu mengembangkan suatu bahan ajar yang disesuaikan dengan model level of inquiry [6]. Bahan ajar yang dikembangkan berupa LKPD, namun berbeda dengan yang digunakan oleh guru sebab LKPD yang dikembangkan terintegrasi dengan tahapan-tahapan dari model level of inquiry.

Salah satu model level of inquiry, yaitu model pembelajaran penemuan. dimana model pembelajaran ini merupakan model yang cukup efektif digunakan karena dapat meningkatkan partisipasi peserta didik selama pembelajaran, melatih dan mengembangkan pemikiran kritis dan kreatif peserta didik, melatih dan mengembangkan pengetahuan prosedural peserta didik, serta dapat membentuk dan mengembangkan kemampuan literasi sains peserta didik [7, 8].

LKPD berbasis pembelajaran penemuan baik diterapkan dalam proses pembelajaran kimia sebab di dalam LKPD tersebut telah diintegrasikan dengan tahapan-tahapan pembelajaran penemuan, sebagaimana hasil penelitian dari Mustofa, dkk [16] yang menyatakan bahwa LKS Berbasis Model Pembelajaran Discovery Learning efektif untuk meningkatkan kemampuan literasi sains siswa.

Berdasarkan uraian di atas, maka dilakukan penelitian yang berjudul "Pengembangan LKPD Berbasis Pembelajaran Penemuan untuk Meningkatkan Kemampuan Literasi Sains Peserta Didik pada Materi Kimia SMA”.

\section{METODE PENELITIAN}

Prosedur pengembangan yang digunakan dalam penelitian ini, yaitu model Dick \& Carey yang diadaptasi dari Walter Dick \& Lou Carey (2001) The Systematic Design of Instruction, dimana model ini merupakan salah satu bagian dari model prosedural [9].

Model Dick \& Carey memiliki sepuluh tahapan antara lain: analisis kebutuhan dan identifikasi tujuan umum, analisis pembelajaran, analisis pembelajar dan konteks, merumuskan tujuan khusus, mengembangkan instrumen penilaian, mengembangkan strategi pembelajaran, mengembangkan dan memilih bahan pembelajaran, evaluasi formatif, melakukan revisi, serta evaluasi sumatif, namun dalam penelitian ini terbatas sampai pada tahap evaluasi formatif saja.

Instrumen yang digunakan untuk mengetahui kelayakan pengembangan LKPD adalah lembar validasi LKPD pada aspek materi dan aspek produk, kegiatan validasi LKPD dilakukan oleh tiga orang dosen ahli dalam bidang Pendidikan dan bidang ilmu kimia. Data yang diperoleh akan dianalisis dengan metode kuantitatif melalui teknik persentase untuk mengetahui kelayakan pengembangan LKPD berbasis pembelajaran penemuan. Tingkat kelayakan dari hasil pengembangan akan dideskripsikan dengan 
mengkonfirmasi persentase hasil penskoran yang diperoleh dengan kriteria kelayakan.

Instrumen yang digunakan untuk mengetahui kepraktisan penggunaan LKPD adalah lembar observasi keterlaksanaan pembelajaran serta respon guru dan peserta didik. Data keterlaksanaan pembelajaran dianalisis deskriptif sedangkan data respon guru dan peserta didik dianalisis dengan metode kuantitatif melalui teknik persentase untuk mengetahui kepraktisan pengembangan LKPD berbasis pembelajaran penemuan. Tingkat kepraktisan dari hasil respon akan dideskripsikan dengan mengkonfirmasi persentase hasil penskoran yang diperoleh dengan kriteria kepraktisan.

Instrumen yang digunakan untuk mengetahui keefektifan penerapan LKPD adalah tes PG literasi sains materi larutan elektrolit dan nonelektrolit. Data tes literasi sains dihitung menggunakan indeks gain untuk mengetahui peningkatan kemampuan literasi sains peserta didik setelah diterapkannya LKPD berbasis pembelajaran penemuan. Tingkat keefektifan dari penerapan tersebut akan dideskripsikan dengan mengkonfirmasi hasil penskoran yang diperoleh dengan kriteria indeks gain.

\section{HASIL DAN PEMBAHASAN Uji Coba Prototipe}

Uji coba prototipe dilakukan secara perorangan yang melibatkan subjek sebanyak 3 orang. Dalam hal ini peneliti melakukan kegiatan validasi produk yang dikembangkan kepada validasi ahli dalam bidang Pendidikan dan bidang ilmu kimia. Validasi ahli dilakukan oleh 3 orang dosen dengan tujuan untuk menguji kelayakan LKPD berbasis pembelajaran penemuan yang dikembangkan.

Tabel 1. Hasil Validasi Kelayakan Pengembangan LKPD Berbasis Pembelajaran Penemuan

\begin{tabular}{clcc}
\hline No. & \multicolumn{1}{c}{$\begin{array}{c}\text { Aspek } \\
\text { Penilaian }\end{array}$} & $\begin{array}{c}\text { Persentase } \\
(\%)\end{array}$ & Kategori \\
\hline 1. & $\begin{array}{l}\text { Kelayakan } \\
\text { Kegrafisan }\end{array}$ & 85,37 & Sangat Layak \\
2. & $\begin{array}{l}\text { Kelayakan Isi } \\
\text { Kelayakan }\end{array}$ & 85,67 & Sangat Layak \\
3. & $\begin{array}{l}\text { Penyajian } \\
\text { Kelayakan }\end{array}$ & 96,67 & Sangat Layak \\
4. & 85,64 & Sangat Layak \\
& $\begin{array}{l}\text { Penilaian } \\
\text { LKPD Berbasis }\end{array}$ & 93,33 & Sangat Layak \\
5. & $\begin{array}{l}\text { Pembelajaran } \\
\text { Penemuan }\end{array}$ & & \\
\hline Rata-Rata Persentase & 89,33 & Sangat Layak \\
\hline
\end{tabular}

Uji kelayakan LKPD berbasis pembelajaran penemuan dilakukan dengan cara memberikan lembar penilaian atau validasi produk yang dikembangkan dalam beberapa aspek, yaitu aspek kelayakan kegrafisan, aspek kelayakan isi, aspek kelayakan penyajian, aspek kelayakan bahasa, dan aspek penilaian LKPD berbasis pembelajaran penemuan. Kelima aspek ini dijadikan sebagai tolak ukur untuk menyatakan layak atau tidaknya LKPD yang dikembangkan. Hasil validasi pengembangan LKPD berbasis pembelajaran penemuan dapat dilihat pada Tabel 1.

Berdasarkan data pada Tabel 1 diketahui bahwa LKPD berbasis pembelajaran penemuan memenuhi kategori sangat layak digunakan dalam proses pembelajaran dengan rata-rata persentase sebesar 89,33\%. Ini menunjukkan bahwa LKPD yang dikembangkan sudah dapat diuji cobakan di sekolah untuk mengetahui kepraktisan dan keefektifan penerapan LKPD tersebut.

LKPD berbasis pembelajaran penemuan dapat dijadikan sebagai alat atau sumber belajar alternatif dalam pembelajaran kimia untuk meningkatkan kemampuan literasi sains dan keterampilan kerja ilmiah peserta didik pada materi larutan elektrolit dan nonelektrolit. Terbukti dari hasil validasi yang telah dilakukan oleh tiga orang validator, dimana rata-rata penilaian LKPD dari berbagi aspek kelayakan mendapatkan kategori sangat layak digunakan dalam proses pembelajaran kimia pada materi larutan elektrolit dan nonelektrolit. Kelayakan teoritis pengembangan LKPD dinyatakan layak digunakan jika tiap-tiap kriteria penilaian memperoleh nilai persentase kelayakan yang sama dengan atau lebih dari $70 \%$ [1].

\section{Uji Coba Lapangan}

Uji coba lapangan dilakukan untuk mengetahui kepraktisan penggunaan LKPD berbasis pembelajaran penemuan dan keefektifan penerapan LKPD tersebut. Uji kepraktisan penggunaan LKPD berbasis pembelajaran penemuan dilakukan dengan melihat keterlaksanaan pembelajaran yang telah dirancang dalam RPP serta respon guru dan peserta didik terkait penggunaan LKPD berbasis pembelajaran penemuan.

Keterlaksanaan pembelajaran atau RPP dapat dilakukan dengan mengamati proses pembelajaraan menggunakan model pembelajaran penemuan. Pengamatan dilakukan oleh observer dengan melihat setiap langkah-langkah kegiatan pembelajaran yang dirancang dalam RPP telah terlaksana dengan baik atau tidak terlaksana. Hasil yang diperoleh dari kegiatan observasi ini berupa analisis deskriptif atau penjabaran kekurangan dan kelebihan dari proses pembelajaran tersebut.

Hasil observasi keterlaksanaan pembelajaran (RPP) menunjukkan bahwa proses pembelajaran yang terjadi pada pertemuan pertama dan pertemuan kedua secara umum baik dan terlaksana seluruhnya. Semua langkah-langkah kegiatan pembelajaran yang mengikuti tahapan dari model pembelajaran penemuan terlaksana seluruhnya. Ini menandakan bahwa model pembelajaran penemuan cocok digunakan dalam proses pebelajaran kimia khususnya pada materi larutan elektrolit dan nonelektrolit. 
Observer juga memberikan catatan yang dapat dijadikan sebagai saran perbaikan bagi peneliti seperti yang terlihat pada Tabel 2 .

Tabel 2. Catatan Saran dan Masukan dari Observer

\begin{tabular}{cl}
\hline No. & \multicolumn{1}{c}{ Saran dan Masukan Observer } \\
\hline 1 & Pemberian apersepsi awal pembeajaran \\
& serta penjelasan metode dan kegiatan yang \\
& dilakukan, cukup banyak dijelaskan oleh \\
& pengajar/guru sehingga peserta didik \\
& sedikit bosan dan kurang memahaminya, \\
& selain itu penjelasannya juga cukup cepat. \\
& Diharapkan agar penjelasannya dapat lebih \\
& sederhana dan tidak terlalu banyak. \\
& Kegiatan pembelajaran memang terlaksana \\
& seluruhnya akan tetapi penyesuaian waktu \\
& per tahapannya sering kelebihan, mungkin \\
& sebaiknya peserta didik diberitahukan \\
& batasan-batasan waktu setiap tahapan \\
& sehingga mereka dapat bekerja lebih cepat. \\
Pengajar/guru terlalu fokus di depan jarang \\
berkeliling untuk memantau peserta didik, \\
meskipun tujuannya adalah belajar secara \\
mandiri seharusnya pengajar/guru tetap \\
memantau peserta didik dalam setiap \\
langkah kegiatannya.
\end{tabular}

Adapun respon guru dan peserta didik terhadap LKPD yang dikembangkan, tujuannya untuk mengetahui kemudahan penggunaan LKPD berbasis pembelajaran penemuan pada materi larutan elektrolit dan nonelektrolit. Hasil respon guru dan peserta didik terhadap LKPD yang dikembangkan dapat dilihat pada Tabel 3.

Tabel 3. Hasil Respon Guru dan Peserta Didik

\begin{tabular}{clcc}
\hline No & Hasil Respon & $\begin{array}{c}\text { Persentase } \\
(\%)\end{array}$ & Kategori \\
\hline 1. & Peserta didik & 78,95 & Baik \\
2. & Guru & 94,64 & Sangat Baik \\
\hline & Rata-Rata & 86,79 & Sangat Baik \\
\hline
\end{tabular}

Berdasarkan data pada Tabel 3 penggunaan LKPD berbasis pembelajaran penemuan pada materi larutan elektrolit dan nonelektrolit memenuhi kategori praktis dan sangat baik digunakan oleh peserta didik dan guru dengan rata-rata persentase sebesar $86,79 \%$. Ini menunjukkan bahwa penggunaan LKPD yang diaplikasikan dengan tahapan pembelajaran penemuan dan terintegrasi dengan indikator keterampilan kerja ilmiah sangat mudah digunakan oleh peserta didik dan guru dalam pembelajaran kimia khususnya pada materi larutan elektrolit dan nonelektrolit.

LKPD berbasis pembelajaran penemuan yang ditujukan untuk melatih dan mengembangkan kemampuan literasi sains peserta didik memiliki point positif dan sangat baik digunakan dalam proses pembelajaran kimia pada materi larutan elektrolit dan nonelektrolit sebab peserta didik dituntut untuk belajar secara langsung atau mandiri dalam menemukan suatu konsep melalui prosedur kerja ilmiah menggunakan langkah-langkah metode ilmiah sehingga dapat melatih dan mengembangkan pemahaman proses sains $[10,11]$ serta secara tidak langsung juga dapat melatih dan mengembangkan kemampuan berpikir kritis dan kreatif peserta didik dalam memecahkan suatu permasalahan yang diberikan [18, 19].

Uji keefektifan penerapan LKPD berbasis pembelajaran penemuan dalam meningkatkan kemampuan literasi sains peserta didik setelah diterapkannya LKPD terebut mendapatkan skor $\mathrm{N}$ gain sebesar 0,36 dan termasuk dalam kriteria Sedang. Artinya peningkatan kemampuan literasi sains peserta didik cukup baik setelah diterapkannya LKPD berbasis pembelajaran penemuan dalam proses pembelajaran sehingga memperoleh hasil yang cukup maksimal.

Adanya peningkatan kemampuan literasi sains peserta didik dikarenakan penyampaian konsep larutan elektrolit dan nonelektrolit banyak menampilkan konteks-konteks yang dekat dengan peserta didik sehingga merangsang keingintahuan mereka serta membuat mereka antusias untuk mencari, mendalami, dan menggali informasi dari materi yang dipelajarinya [12].

Meskipun terjadi peningkatan kemampuan literasi sians setelah diterapkannya LKPD berbasis pembelajaran penemuan, ini tidak dapat dijadikan sebagai tolak ukur bahwa seluruh peserta didik sudah memiliki kemampuan literasi sains yang baik, sebab jika tidak dilatih dan dikembangkan secara terusmenerus kemungkinan peserta didik untuk memahami sains dalam literasi sains menjadi rendah atau kurang sehingga tidak ada kebermaknaan dari proses pembelajaran yang telah berlangsung sebelumnya [11].

Karena sejatinya, tujuan dari pendidikan sains adalah dapat mengembangkan sikap peserta didik dan membuat mereka tertarik pada isu ilmiah, kemudian memperoleh dan mengaplikasikan pengetahuan sains dan teknologi tersebut untuk keuntungan pribadi, sosial, dan global [13] serta mengembangkan kemampuan berpikir analisis peserta didik dalam memecahkan masalah sebab mereka diberikan kesempatan unuk mengenali, menemukan, dan mencari tahu berbagai aplikasi sains dalam kehidupan sehari-hari [17]. Kemudian data hasil ketuntasan indikator kompetensi literasi sains yang dapat dillihat pada Gambar 1. 


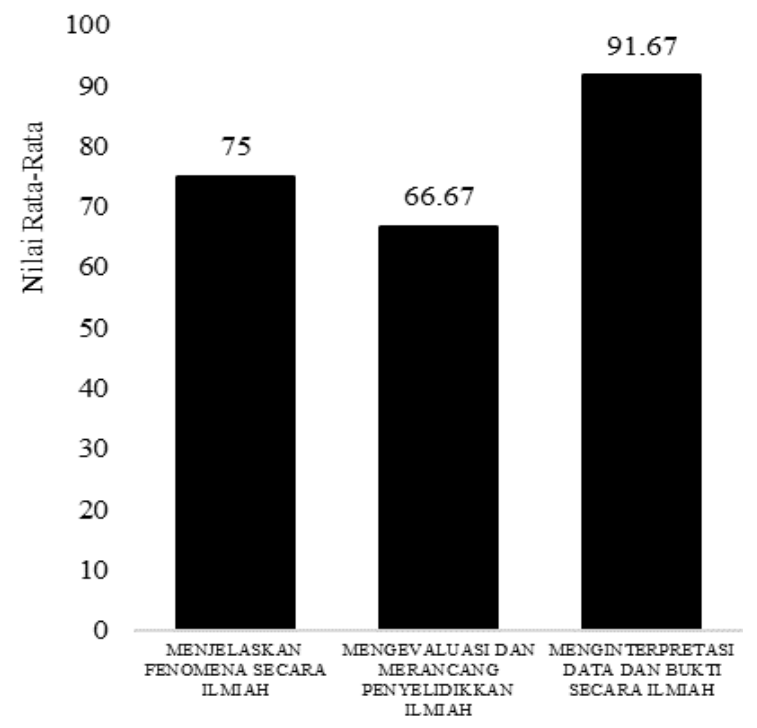

Gambar 1. Hasil Ketuntasan Indikator Kompetensi Literasi Sains Peserta Didik

Kompetensi literasi sains pertama, yaitu menjelaskan fenomena secara ilmiah, nilai rata-rata peserta didik pada kompetensi ini sebesar 75. Ini menunjukkan bahwa kemampuan peserta didik dalam menjawab soal-soal literasi sains materi larutan elektrolit dan nonelektrolit pada kompetensi menjelaskan fenomena secara ilmiah termasuk dalam kategori baik. Kompetensi menjelaskan fenomena secara ilmiah menuntut peserta didik untuk mengingat pengetahuan konten yang tepat dalam situasi yang diberikan dan menggunakannya untuk menginterpretasi dan memberi sebuah penjelasan terhadap fenomena yang diajukan [4].

Peningkatan yang tinggi pada domain kompetensi ini dapat terjadi karena tahapan-tahapan dari model pembelajaran penemuan yang diterapkan dalam pembelajaran banyak memfasilitasi peserta didik untuk dapat menjelaskan fenomena secara ilmiah [14]. Proses pembelajaran dengan menerapkan tahapan-tahapan model pembelajaran penemuan pada kompetensi menjelaskan fenomena secara ilmiah, peserta didik dituntut untuk dapat membuat pertanyaan ilmiah, memberikan prediksi atau dugaan sementara, dan menerapkan konsep yang diketahui berdasarkan pengetahuan awal yang dimiliki $[14,12]$.

Kompetensi literasi sains kedua, yaitu mengevaluasi dan merancang penyelidikan ilmiah, dimana nilai rata-rata peserta didik pada kompetensi ini sebesar 66,67. Ini menunjukkan bahwa kemampuan peserta didik dalam menjawab soal-soal literasi sains materi larutan elektrolit dan nonelektrolit pada kompetensi mengevaluasi dan merancang penyelidikan ilmiah termasuk dalam kategori baik. Kompetensi mengevaluasi dan merancang penyelidikan ilmiah menuntut peserta didik untuk dapat menggunakan pengetahuan dan pemahaman tentang penyelidikan ilmiah, mengidentifikasi pertanyaan yang dapat dijawab dengan penyelidikan ilmiah, mengidentifikasi apakah prosedur pendekatan yang dipunyai dapat digunakan, dan mengajukan cara yang paling mungkin untuk menjawab pertanyaan [4].

Proses pembelajaran dengan menerapkan tahapan-tahapan model pembelajaran penemuan ditujukan untuk melatih peserta didik dalam menentukan variabel bebas, variabel terikat, dan variabel kontrol yang sesuai dengan topik permasalahan untuk suatu percobaan. Selain itu, peserta didik juga dilatih dalam menerapkan pengetahuan prosedural untuk melakukan kegiatan evaluasi dan merancang penyelidikan ilmiah [14, 18].

Kompetensi literasi sains ketiga, yaitu menginterpretasi data dan bukti secara ilmiah, dimana nilai rata-rata peserta didik pada kompetensi ini sebesar 91,67. Ini menunjukkan bahwa kemampuan peserta didik dalam menjawab soal-soal literasi sains materi larutan elektrolit dan nonelektrolit pada kompetensi menginterpretasi data dan bukti secara ilmiah termasuk dalam kategori sangat baik.

Kompetensi menginterpretasikan data dan bukti secara ilmiah menuntut peserta didik untuk dapat menganalisis dan mengevaluasi data dalam representasi sebuah tabel atau grafik serta menggambarkan kesimpulan ilmiah secara tepat. Setiap tahapan dari model pembelajaran penemuan yang diterapkan telah memfasilitasi peserta didik untuk dapat mengembangkan kompetensi ini, sebab cara yang tepat untuk melatih kompetensi ini secara maksimal adalah inquiry lab, yaitu kegiatan yang melatih peserta didik untuk membuat dan menganalisis tabel data percobaan, menginterpretasikan data hasil percobaan, dan menarik kesimpulan yang tepat berdasarkan data dan bukti percobaan yang telah dilakukan $[14,19]$.

Pencapaian kemampuan literasi sains peserta didik pada indikator menginterpretasi data dan bukti secara ilmiah ini tergambar dari kemampuan peserta didik dalam menafsirkan bukti ilmiah dan menarik kesimpulan dengan menginterpretasi data yang terdapat pada beberapa tabel dan gambar-gambar pada instrumen soal tes literasi sains [15], khususnya tes PG literasi sains materi larutan elektrolit dan nonelektrolit yang digunakan dalam penelitian ini. Selain itu, kemampuan peserta didik dalam menggunakan bukti ilmiah ditunjukkan dengan mengidentifikasi asumsi, bukti, dan alasan di balik kesimpulan yang ditarik dalam memecahkan masalah seputar konsep materi larutan elektrolit dan nonelektrolit [4].

\section{KESIMPULAN}

Berdasarkan hasil penelitian yang telah dilakukan, maka dapat disimpulkan bahwa pengembangan LKPD berbasis pembelajaran penemuan layak digunakan dengan persentase ratarata aspek penilaian LKPD sebesar 89,33\% dan termasuk dalam kriteria sangat layak, praktis dan 
mudah digunakan oleh guru dan peserta didik dengan persentase rata-rata hasil respon sebesar $86,79 \%$ dan termasuk dalam kriteria sangat baik, serta efektif dalam meningkatkan kemampuan literasi sains peserta didik dengan nilai $N$-gain sebesar 0,36 dan termasuk dalam kategori sedang.

\section{DAFTAR PUSTAKA}

[1] Aisyah. Dwiningsih, K. (2017). Pengembangan Lembar Kegiatan Siswa (LKS) Berorientasi Literasi Sains Pada Materi Larutan Elektrolit dan Nonelektrolit. Journal of Chemical Education, 6(2), 329-333

[2] Dewi, P. S., Rochintaniawati, D. (2016). Kemampuan Proses Sains Siswa Melalui Pendekatan Saintifik dalam Pembelajaran IPA Terpadu Pada Tema Global Warming. EDUSAINS, 8(1), 19-26

[3] Astuti, Y. K. (2016). Literasi Sains dalam Pembelajaran IPA. 2(3B)

[4] OECD. (2017). PISA 2015 Assessment and Analytical Framework. http://www.oecd.org diakses 7 Mei 2019

[5] Nurhidayah, R., Irwandi, D., Saridewi, N. (2015). Pengembangan Modul Berbasis Inkuiri Terbimbing Pada Materi Larutan Elektrolit dan Non-elektrolit. EDUSAINS, 7(1), 37-47

[6] Handoko, A., Sajidan. Maridi. (2016). Pengembangan Modul Biologi Berbasis Discovery Learning (Part of Inquiry Spectrum Learning-Wenning) Pada Materi Bioteknologi Kelas XII IPA di SMA Negeri 1 Magelang Tahun Ajaran 2014/2015. Jurnal Inkuiri, 5(3), 144-154

[7] Muttaqiin, A., Sopandi, W. (2016). Pengaruh Model Discovery Learning Dengan Sisipan Membaca Kritis Terhadap Kemampuan Berpikir Kritis Siswa. EDUSAINS, 8(1), 58-65

[8] Qurniati, D., Andayani, Y., Muntari. (2015). Peningkatan Keterampilan Berpikir Kritis Melalui Model Pembelajaran Discovery Learning. Jurnal Penelitian Pendidikan IPA, 1(2)

[9] Setyosari, P. 2013. Metode Penelitian Pendidikan dan Pengembangan. Jakarta: Prenada Media Grup

[10] Widiadnyana, I. W., Sadia, I. W., dan Suastra, I. W. (2014). Pengaruh Model Discovery Learning Terhadap Pemahaman Konsep IPA dan Sikap Ilmiah Siswa SMP. e-Journal Program Pascasarjana Universitas Pendidikan Ganesha Program Studi IPA, 4

[11] Mirnawati. Rusdiana, D. (2016). Implementasi Model Pembelajaran Discovery untuk Mengembangkan Keterampilan Dasar Bekerja Ilmiah pada Materi Indera Penglihatan dan Alat Optik. EDUSAINS, 8(2), 136-144

[12] Bahriah, E. S. (2015). Peningkatan Literasi Sains Calon Guru Kimia pada Aspek Konteks
Aplikasi dan Proses Sains. EDUSAINS, 7(1), 11-17

[13] Hartati, R. (2016). Peningkatan Aspek Sikap Literasi Sains Siswa SMP melalui Penerapan Model Problem Based Learning pada Pembelajaran IPA Terpadu. EDUSAINS, 8(1), 90-97

[14] Rohmi, P. (2017). Peningkatan Domain Kompetensi dan Pengetahuan Siswa melalui Penerapan Levels of Inquiry dalam Pembelajaran IPA Terpadu. EDUSAINS, 9(1), 14-23

[15] Wulandari, N., Sholihin, H. (2016). Analisis Kemampuan Literasi Sains pada Aspek Pengetahuan dan Kompetensi Sains Siswa SMP pada Materi Kalor. EDUSAINS, 8(1), 6673

[16] Mustofa, A., Kuswanti, R., dan Hidayati, S. N. (2017). Keefektifan LKS Berbasis Model Pembelajaran Discovery Learning untuk Meningkatkan Kemampuan Literasi Sains. EJurnal Pensa, 5(1), 27-32

[17] Qomaliyah, E. N., Sukib, S., \& Loka, I. N. (2017). Pengaruh Model Pembelajaran Inkuiri Terbimbing Berbasis Literasi Sains Terhadap Hasil Belajar Materi Pokok Larutan Penyangga. Jurnal Pijar Mipa, 11(2)

[18] Zakrah, Z., Lestari, N., \& Kusmiyati, K. (2015). Pengaruh Strategi Pembelajaran Discovery Terhadap Kemampuan Berpikir Kritis Siswa pada Mata Pelajaran IPA Kelas VIII di SMPN 3 Gunungsari tahun ajaran 2014/2015. Jurnal pijar MIPA, 10(2)

[19] Ishak, M., Jekti, D. S. D., \& Sridana, N. (2017). Pengaruh Penerapan Pendekatan Saintifik Menggunakan Model Pembelajaran Discovery Dan Kooperatif Tipe Stad Terhadap Kemampuan Berpikir Kreatif Peserta Didik SDN 13 Ampenan. Jurnal Pijar Mipa, 12(1) 